\title{
THE EFFECTS OF HIGH DOSE AND LOW DOSE PROTOCOLS IN THORAX'S CT SCAN IMAGE QUALITY
}

\author{
Ni Larasati Kartika Sari ${ }^{*}$, Deni Tiko Bahagia ${ }^{1}$, Puji Hartoyo ${ }^{1}$, dan Dewi \\ Muliyati $^{2}$ \\ ${ }^{1}$ Program Studi Fisika, Fakultas Teknik dan Sains, Universitas Nasional, Jakarta \\ ${ }^{2}$ Program Studi Pendidikan Fisika, Universitas Negeri Jakarta, Jakarta, Indonesia \\ *nilarasati@civitas.unas.ac.id
}

Received 06-02-2021, Revised 08-08-2021, Accepted 21-08-2021, Published 1-10-2021

\begin{abstract}
The aim of this research was to evaluate the effects of two different dose protocols' usage on image quality. This research was performed on three different CT Scanners using high dose and low dose protocols of thorax scan. Different exposure parameters were used, depending on each scanner's setting. GE QA CT Scan phantom was used for image quality assessment. Image quality measured were CT number accuracy, uniformity and linearity, noise uniformity, spatial resolution and Contrast To Noise Ratio (CNR). CT Scan's dose index, CTDIvol (Volumetric Computed Tomography Dose Index), was also measured to evaluate how these two protocols work in reducing radiation dose. The result showed that the usage of low dose protocols reduce the CTDIvol value at $85-91 \%$ compared to the high dose protocols, meanwhile most of the image quality parameters obtained from both protocols were still considered good. The CT number accuracy, uniformity, linearity and noise uniformity for all CT Scans were all still inside BAPETEN's (Indonesia National Regulator Agency) threshold. There were 20-23\% difference on the spatial resolution value measured from both protocols. The most significant difference came from CNR. The CNR obtained from high dose protocols were $65-93 \%$ higher than the one from low dose protocols.
\end{abstract}

Keywords: contrast to noise ratio, CTDIvol, CT number, spatial resolution

\section{ABSTRAK}

Penelitian ini mengevaluasi pengaruh penggunanaan protokol dosis tinggi dan protokol dosis rendah terhadap kualitias citra dan dosis khususnya pada pemeriksaan CT Scan thorax. Penelitian ini dilakukan pada 3 sampel CT Scan yang berbeda. Faktor eksposi yang digunakan berbeda untuk tiap scanner, bergantung pada setting yang terdapat pada scanner. Fantom yagdigunakan untuk menilai kualitas citra adalah fantom GE QA CT Scan. Adapun kualitas citra yang diukur adalah keseragaman, akurasi, dan linearitas CT number, keseragaman noise, resolusi spasial, serta Contrast to Noise Ratio (CNR). Sementara dosis radiasi yang diamati adalah CTDIvol (Volumetrik Computed Tomography Dose Index) yang tampil pada konsol. Hasil penelitian ini menunjukkan bahwa penggunaan protokol dosis rendah mampu mengurangi nilai CTDIvol sebesar $85-91 \%$ dibanding dengan protokol dosis tinggi, sementara sebagian besar parameter kualitas citra yang diukur masih dinilai baik. Nilai akurasi, keseragaman, dan linearitas CT number serta keseragaman noise pada protokol dosis tinggi dan dosis rendah, keseluruhannya masih dalam batas ambang BAPETEN. Terdapat perbedaan sebesar 20-23\% pada nilai resolusi spasial yang terukur dari kedua protokol. Nilai CNR pada protokol dosis tinggi lebih baik dari pada protokol dosis rendah, dengan perbedaan yang cukup signifikan, yaitu 65-93\%.

Kata kunci: contrast to noise ratio, CTDIvol, CT number, resolusi spasial 


\section{PENDAHULUAN}

CT Scan adalah salah satu modalitas pencitraan medis yang menggunakan prinsip tomografi. CT Scan merupakan modalitas utama dalam beberapa permeriksaan dikarenakan kualitas citranya yang baik, mampu menampilkan citra anatomi tubuh manusia secara dua dimensi berupa citra irisan aksial, sagital, coronal serta dapat direkonstruksi menjadi tampilan tiga dimensi. Kualitas citra CT Scan dapat diukur dengan parameter seperti akurasi CT number, noise, Contrast to Noise Ratio (CNR), dan resolusi spasial. Dibanding dengan modalitas pencitraan lain, CT Scan memberikan radiasi dosis yang tinggi ke pasien, yang dapat memicu kanker ${ }^{[1,2]}$. Pemeriksaan rutin CT Scan thorax memberikan dosis 100 kali lebih besar dibanding pemeriksaan rutin thorax radiografi ${ }^{[3]}$. CT Scan juga menyumbang $60 \%$ dari dosis yang diterima akibat pencitran medis ${ }^{[4]}$. Diestimasikan $44 \%$ nilai kolektif dosis efektif global berasal dari pemeriksaan CT Scan ${ }^{[5]}$. Kualitas citra CT Scan yang dihasilkan juga dipengaruhi dosis radiasi yang diterima tubuh. Sehingga dibutuhkan protokol yang didesain klinis agar pasien mendapat dosis As Low As Reasonably Achieveable (ALARA) namun tetap mempertahankan kualitas citra.

Banyak strategi telah dilakukan untuk mengurangi dosis radiasi pada pemeriksaan CT Scan, diantaranya modulasi arus tabung otomatis atau biasa disebut Automatic Exposure Control $(\mathrm{AEC})^{[6]}$, meningkatkan pengaturan noise yang diterima ${ }^{[7]}$, serta penggunaan algoritma rekonstruksi dengan teknik iterasi ${ }^{[8,9]}$. Penggunaan AEC pada pemeriksaan CT Scan telah terbukti tetap menghasilkan kualitas citra yang baik dari segi CT number dan $n o i s e^{[10]}$. Salah satu inovasi vendor CT Scan lainnya untuk optimisasi dosis adalah dengan membuat dua protokol scanning yaitu low dose dan high dose protocols. Keduanya memiliki perbedaan dalam hal nilai arus tabung $(\mathrm{mA})$ dan tegangan tabung $(\mathrm{kVp})$ yang digunakan, sehingga tentunya akan menghasilkan perbedaan kualitas citra $^{[11]}$. Pengurangan parameter dosis, seperti tegangan tabung, arus tabung dan pitch, telah terbukti tidak mengubah kualitas citra secara signifikan pada pemeriksaan head and neck ${ }^{[12]}$. Pengurangan arus tabung dari $500 \mathrm{ke}$ $100 \mathrm{mAs}$ dapat meningkatkan noise sebanyak $40 \%^{[13]}$. Pengurangan dosis yang berlebihan dapat menghasilkan citra dengan kualitas terlampau rendah dan mungkin tidak dapat digunakan untuk diagnosis ${ }^{[14]}$.

Oleh karena itu, penelitian ini bermaksud untuk mengevaluasi efek penggunakan protokol dosis tinggi dan dosis rendah dari berbagai merk CT Scan, terhadap kualitas citra, khususnya pemeriksaan thorax.

\section{METODE}

Penelitian ini bertujuan untuk untuk mengevaluasi efek penggunaan protokol dosis tinggi dan dosis rendah terhadap kualitas citra CT Scan Thorax. Penelitian ini dilakukan pada 3 CT Scan dari vendor Siemens, Toshiba dan GE dengan spesifikasi CT Scan 16 slice merk Toshiba Alexion tipe TSX-032A dengan nomor seri 1AA1272567 dengan kondisi maksimum 135 kV. Selain itu, CT Scan 16 slice merk Siemens S Somatom emotion 16, seri: 86669 dengan tegangan tabung maksimal $130 \mathrm{kV}$, serta CT Scan 16 slice merk GE Optima dengan kondisi maksimum $140 \mathrm{kV}$ dan $200 \mathrm{~mA}$. Faktor eksposi yang digunakan sesuai dengan protokol dosis tinggi dan rendah masing-masik merk. Nilai faktor eksposi tersebut dapat dilihat pada Tabel 1. Diantara ketiga merk, GE memiliki faktor eksposi tertinggi untuk protokol dosis tinggi. 
Tabel 1. Parameter Faktor eksposi dari masing masing CT Scan

\begin{tabular}{ccccc}
\hline Protokol & Siemens & GE & Toshiba & Pitch \\
\hline $\begin{array}{c}\text { Dosis Tinggi } \\
\text { (kVdan mAs) }\end{array}$ & $130 \mathrm{kV}$ & $140 \mathrm{kV}$ & $135 \mathrm{kV}$ & $0,8 \mathrm{~mm}$ \\
& $200 \mathrm{mAs}$ & $300 \mathrm{mAs}$ & $\begin{array}{c}52 \mathrm{mAs} \\
\text { (setting otomatis) }\end{array}$ & \\
$\begin{array}{c}\text { Dosis Rendah } \\
\text { (kV dan mAs) }\end{array}$ & $100 \mathrm{mAs}$ & $80 \mathrm{kV}$ & $80 \mathrm{kV}$ & $0,8 \mathrm{~mm}$ \\
& $100 \mathrm{mAs}$ & $\begin{array}{c}52 \mathrm{mAs} \\
\text { (setting otomatis) }\end{array}$ & \\
\hline
\end{tabular}

Objek scan menggunakan fantom QA CT, seperti pada Gambar 1. Fantom terdiri dari beberapa modul, diantaranya modul yang tersusun atas bahan homogen untuk uji CT number dan noise, modul yang terdiri dari material setara air, udara, dan akrilik, serta modul uji resolusi spasial yag terdiri dari pasang garis. Evaluasi kualitas citra meliputi keseragaman $C T$ number, akurasi CT number, keseragaman noise, linearitas CT number, Contrast to Noise Ratio (CNR), dan resolusi spasial.
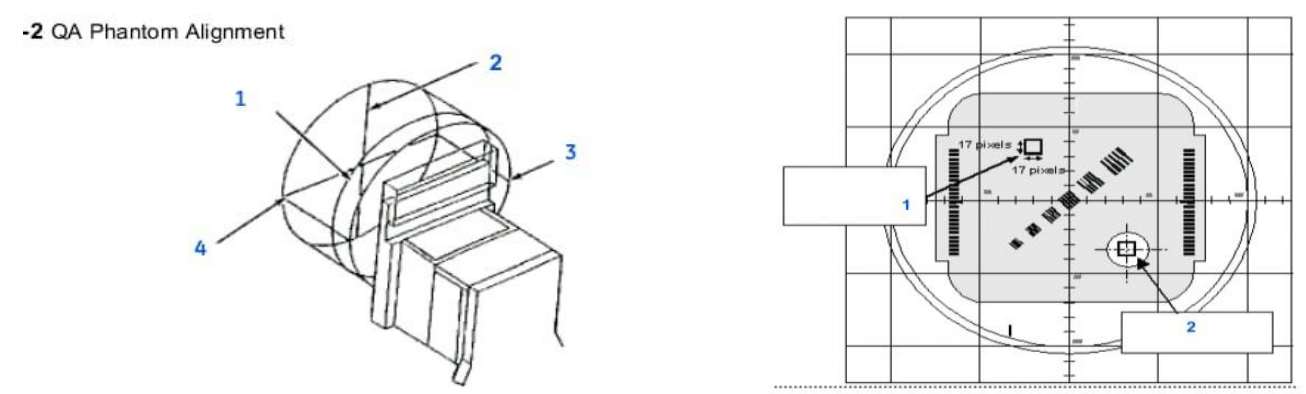

Gambar 1. Fantom QA CT Scan

CT number merupakan angka yang menyatakan nilai koefisien atenuasi objek yang dicitrakan relatif terhadap koefisien atenuasi air, seperti pada persamaan 1 . Nilai CT number bervariasi dari mulai 500-3000 HU untuk tulang, 0 untuk air, hingga -300 - -800 untuk paru paru $^{[2]}$. Evaluasi $C T$ number dilakukan dengan memindai bagian modul homogen dari fantom yang terbuat dari bahan setara air. Citra dari objek homogen seharusnya memiliki nilai $C T$ number yang juga seragam di segala sisi. Selain itu, karena fantom terbuat dari material setara air, maka nilai $C T$ number dari citra harus setara dengan nilai $C T$ number air, yaitu 0, atau berkisar dari 4 hingga -4 , sesuai dengan standar uji kesesuaian Bapeten.

$$
\text { CT Number }=\frac{\mu_{t}-\mu_{w}}{\mu_{w}} \times 1000
$$

Dimana $\mu_{\mathrm{t}}$ adalah koefisien atenuasi dari jaringan yang terukur dan $\mu_{\mathrm{w}}$ adalah koefisien atenuasi air ${ }^{[2]}$.

Pengukuran nilai akurasi $C T$ number dan keseragaman $C T$ number dilakukan dengan membuat Region of Interest (ROI) di console dengan kondisi window width 350 dan window level 40. ROI dibuat dengan diameter seragam yaitu $209 \mathrm{~mm}^{2}$. ROI untuk akurasi $C T$ number dibuat pada bagian tengah citra, sementara untuk keseragaman $C T$ number 
pengukuran dilakukan pada lima titik, yaitu di tengah citra, dan pada bagian tepi arah jam 12, 3, 6, dan 9 seperti pada Gambar 2a. Nilai rata-rata CT number atau Houndsfield Unit (HU) pada ROI diukur. Hasil pengukuran selanjutnya di evaluasi sesuai rekomendasi pada Perka Bapeten no. 2 tahun 2018, dimana nilai CT number pada pusat citra adalah -4 sampai 4, serta selisih $C T$ number dari ROI di pusat citra dengan $C T$ number tepi citra adalah -2 sampai $2^{[15]}$.

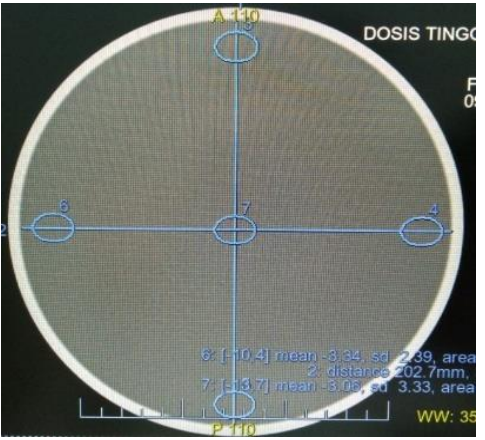

(a)

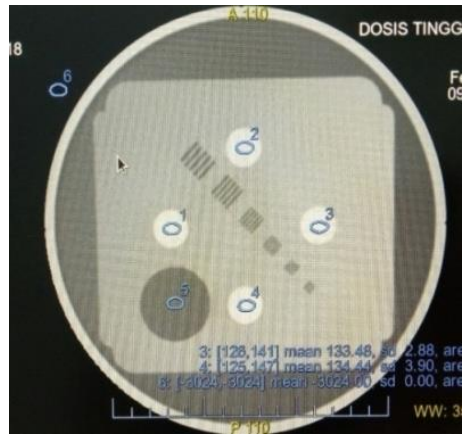

(b)

Gambar 2. Hasil scan fantom QA CT Scan. (a) untuk pengukuran keserangaman CT number, (b) untuk pengukuran linearitas CT number

Evaluasi linearitas $C T$ number bertujuan untuk menilai apakah sistem pencitraan mampu menghasilkan citra yang sesuai dengan densitas dari objek yang dicitrakan. Objek dengan densitas lebih tinggi harus tampak lebih terang dari objek dengan densitas rendah. Pengukuran dilakukan pada citra hasil pemindaian fantom pada material akrilik, water dan udara, seperti ggambar $2 b$. Selanjutnya dibuat grafik nilai rata-rata $C T$ number terhadap densitas elektron pada ketiga material. Koefisien linearitas grafik harus memenuhi $\mathrm{R} \geq$ 0,990 .

Noise merupakan besaran yang menyatakan variasi dari nilai CT number (sumber). Noise diukur pada citra hasil pemindainan bagian modul homogen dari fantom, seperti pada $C T$ number. Oleh karena itu, nilai noise pada berbagai posisi citra juga harus seragam. Pengukuran keseragaman noise dilakukan pada titik-titik tertentu di citra, seperti pada keseragaman $C T$ number. Namun, nilai yang diukur bukan nilai rata-rata $C T$ number, melainkan nilai standar deviasinya. Hasil pengukuran juga dibandingkan dengan rekomendasi BAPETEN, yaitu selisih standar deviasi dari ROI di pusat citra dengan standar deviasi tepi citra adalah -2 sampai 2 .

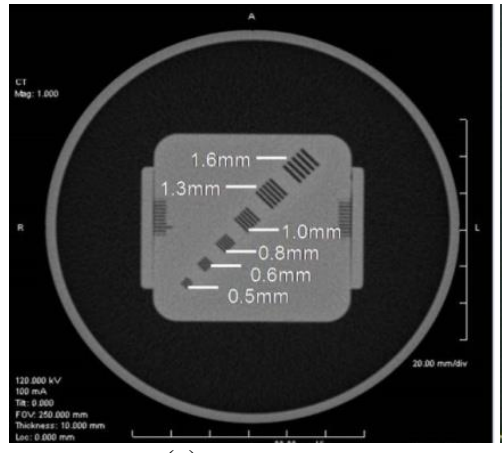

(a)

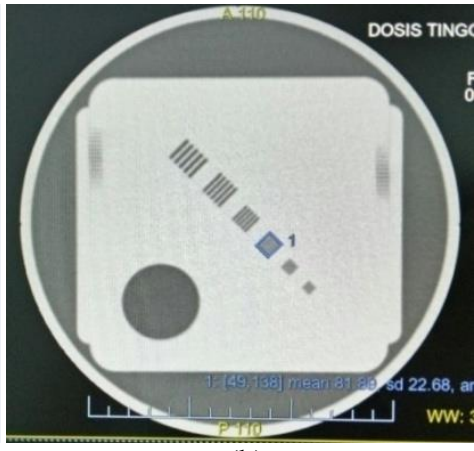

(b)

Gambar 3. Pengukuran resolusi spasial. (a) Keterangan referensi nilai resolusi spasial (b) Hasil scan fantom modul resolusi spasial 
Resolusi spatial menyatakan kemampuan untuk membedakan objek kecil dengan posisi berdekatan. Pengukuran resolusi spatial dilakukan pada citra hasil pemindaian modul line pair pada fantom, dengan melihat pasang garis mana yang masih nampak jelas secara dapat dibedakan secara visual, seperti pada Gambar 3. Pengukuran resolusi spasial lebih lanjut juga dilakukan dengan membuat grafik profil dengan menggunakan aplikasi ImageJ. Resolusi spatial berkaitan dengan ketelitian kedetail-an sistem pencitraan, sehingga semakin banyak pasang garis yang dapat nampak pada citra, maka semakin detail citra, dan semakin baik resolusi spasial.

Contrast to Noise Ratio (CNR) merupakan besaran untuk menilai kemampuan sistem pencitraan untuk menghasilkan citra object dengan jelas pada kondisi noise pada latar belakang. Evaluasi CNR dilakukan dengan mengukur nilai rata-rata $C T$ number pada citra objek dan background, serta nilai standar deviasi background dari hasil pemindaian fantom. Selanjutnya, nilai CNR diolah dengan menggunakan Persamaan $2^{[2]}$.

$$
C N R=\frac{P i-P b}{\sqrt{S D i^{2}+S D b^{2}}}
$$

Dimana $\mathrm{Pi}$ adalah nilai $C T$ number rata-rata objek, $\mathrm{Pb}$ adalah nilai $C T$ number rata-rata background, SDi adalah standar deviasi objek, dan SDb adalah standar deviasi background $^{[2]}$.

Selain kualitas citra, nilai CTDI (Computed Tomography Dose Index) yang tertera pada console juga dicatat untuk membandingkan apakah penggunaan protokol dosis tinggi dan rendah memberikan perbedaan keluaran dosis. CTDI merupakan indeks dosis pada pemeriksaan $C T$ Scan yang dapat digunakan sebagai dasar dalam mengestimasi dosis pasien $^{[16]}$. CTDI biasanya diukur pada fantom khusus dan dengan menggunakan pencil ion chamber dengan panjang $100 \mathrm{~mm}$, seperti pada Gambar 4, sehingga dinamakan CTDI 100 . Pengukuran $\mathrm{CTDI}_{100}$ dilakukan pada posisi tengah fantom dan tepi fantom. Gabungan nilai $\mathrm{CTDI}_{100}$ pada posisi tengan dan tepi fantom disebut CTDIw. CTDIw dapat dilihat pada Persamaan $3^{[17]}$.

$$
\text { CTDIw }=1 / 3 \text { CTDI }_{100, \text { pusat }}+2 / 3{ }^{2} \text { CTDI } 100, \text { tepi }
$$

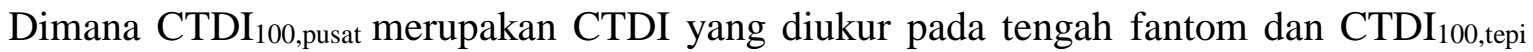
adalah CTDI yang diukur pada posisi tepi fantom ${ }^{[18]}$. Sementara itu, CTDI yang tertera pada console merupakan CTDIvol. CTDIvol mewakili dosis rata-rata untuk scan volum (3D pada mode helical). CTDI vol dirumuskan pada persamaan $4^{[17]}$.

$$
\text { CTDIvol }=\frac{C T D I_{w}}{p i t c h}
$$

Dimana pitch merupakan pergerakan tabel searah sumbu z (dalam $\mathrm{mm}$ ) saat rotasi penuh berlangsung (360 derajat) dibagi dengan lebar berkas (dalam $\mathrm{mm}$ ). 


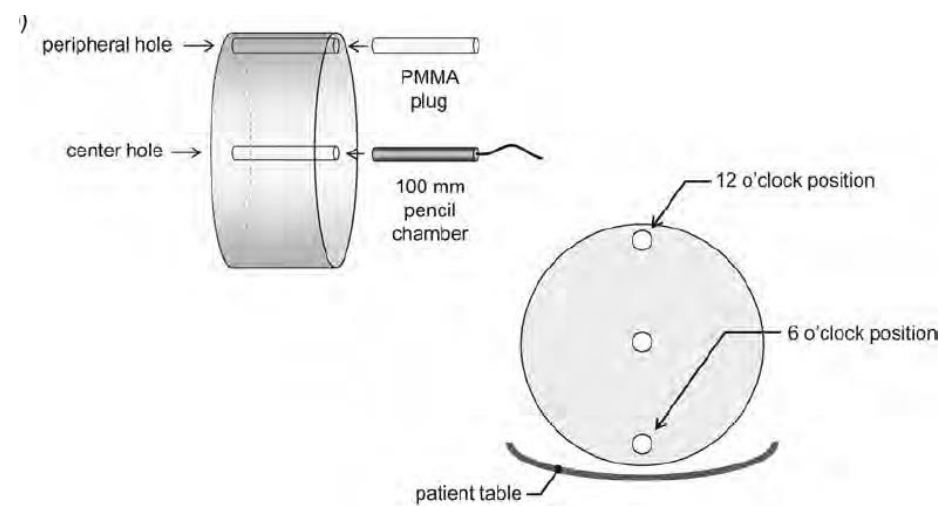

Gambar 4. Pengukuran CTDI pada fantom khusus dengan pencil ion chamber sepanjang $100 \mathrm{~mm}^{[17]}$

\section{HASIL DAN PEMBAHASAN}

Tabel 2. Hasil Akurasi CT number dari 3 modalitas CT Scan

\begin{tabular}{ccccc}
\hline \multirow{2}{*}{ Protokol } & \multicolumn{3}{c}{ Modalitas CT Scan 16 Slice } & \multirow{2}{*}{$\begin{array}{c}\text { Ambang batas } \\
\text { BAPETEN }\end{array}$} \\
\cline { 2 - 4 } & Toshiba & Siemens & GE & \\
\hline Tinggi & $-0,20$ & $-2,8$ & $-3,06$ & $-4 \leq \mathrm{CT} \leq 4$ \\
Rendah & $-1,50$ & $-3,14$ & $-3,95$ & \\
Persentase & $65 \%$ & $12,14 \%$ & $29,08 \%$ & \\
perbedaan & & & & \\
\hline
\end{tabular}

Berdasarkan hasil Tabel 2, nilai akurasi CT number dengan protokol dosis tinggi dan rendah masih memilki rentang nilai baseline yang sesuai dengan rekomendasi BAPETEN yaitu berada pada range $-4 \leq \mathrm{CT} \leq 4$. Nilai $C T$ number dari CT Scan GE dengan protokol dosis rendah adalah $-3,95$, hampir mendekati nilai batas ambang dari BAPETEN. Persentase perbedaan antara akurasi $C T$ number dengan protokol dosis tinggi dan dosis rendah yang dihasilkan pada merk Toshiba adalah yang paling signifikan, yaitu, $65 \%$. Selain itu, nilai CT number yang terukur dari ketiga merk CT Scan tidaklah sama walaupun diambil dengan protokol yang sama. Hal ini salah satunya disebabkan oleh perbedaan faktor eksposi seperti yang tertera pada tabel 1. Tiap merk memiliki perbedaan setting $\mathrm{kV}$ dan $\mathrm{mAs}$ pada tiap protokol. Perbedaan penggunaan $\mathrm{kV}$ dan $\mathrm{mAs}$ mempengaruhi energi dan intensitas berkas foton sehingga menghasilkan nilai $C T$ number yang berbeda ${ }^{[18,19]}$. Selain itu, perbedaan algorithma rekonstruksi juga mempengaruhi nilai $C T$ number ${ }^{[19]}$. GE menggunakan algoritma ASIR (Adaptive Statistical Iterative Reconstruction), Siemens SAFIRE (Sinogram Affirmed Iterative Reconstruction), dan AIDR 3D (Adaptive Iterative Dose Reduction $3 D)^{[20]}$. Fungsi algoritma itu sendiri adalah untuk melakukan proses pemprosesan citra secara digital untuk dapat menghasilkan kualitas citra yang baik, dilihat dari noise, CNR dan nilai $\mathrm{HU}^{[20]}$.

Nilai keseragaman CT number juga masih berada dalam rentang ambang batas BAPETEN, seperti yang tertera pada tabel 3 . Persentase perbedaan antara keseragaman $C T$ number dengan protokol dosis tinggi dan dosis rendah yang paling signifikan dihasilkan pada merk GE, yaitu 58,75 \%. Selain itu, nilai keseragaman CT number merk GE protokol dosis rendah hampir mendekati batas ambang BAPETEN. Hal ini konsisten terhadap hasil akurasi $C T$ number pada tabel 2, yang artinya penggunaan protokol dosis rendah pada CT Scan GE menghasilkan kualitas citra yang paling rendah dalam hal akurasi dan keseragaman $C T$ number. 
Tabel 3. Hasil Keseragaman CT number dari 3 modalitas CT Scan

\begin{tabular}{ccccc}
\hline \multirow{2}{*}{ Protokol } & \multicolumn{3}{c}{ Modalitas CT Scan } & \multirow{2}{*}{$\begin{array}{c}\text { Ambang Batas } \\
\text { BAPETEN }\end{array}$} \\
\cline { 2 - 4 } & Toshiba & Siemens & GE & \\
\hline Tinggi & 0,930 & 0,310 & 0,280 & $\leq \pm 2$ CT/HU \\
Rendah & 1,310 & $-0,800$ & 1,925 & \\
$\begin{array}{c}\text { Persentase } \\
\text { perbedaan }\end{array}$ & $40,86 \%$ & $36 \%$ & $58,75 \%$ & \\
\hline
\end{tabular}

Nilai linearitas $C T$ number dari ketiga pesawat CT Scan menunjukan nilai $\mathrm{R} \geq 0,990$, yang berarti hasil citra dari ketiga pesawat masih memenuhi standar BAPETEN. Berdasarkan Tabel 5, persentase perbedaan tertinggi antara penggunaan protokol dosis tinggi dan dosis rendah terdapat pada CT Scan Toshiba, yaitu $0,12 \%$. Nilai linearitas CT number menunjukkan bahwa hubungan antara $C T$ number citra dengan densitas material obyek scan adalah linear, sehingga citra benar-benar menampilkan perbedaan greyscale sesuai dengan densitas objek scan. Perubahan faktor eksposi tidak memberikan efek yang besar terhadap feature-feature radiomic dari citra CT Scan ${ }^{[21]}$.

Tabel 4. Linearitas CT Number dari 3 modalitas CT Scan

\begin{tabular}{ccccc}
\hline & \multicolumn{3}{c}{ Modalitas CT Scan } & \multirow{2}{*}{$\begin{array}{c}\text { Ambang } \\
\text { batas } \\
\text { Protokol }\end{array}$} \\
\cline { 2 - 4 } & Toshiba & Siemens & GE & BAPETEN \\
\hline Tinggi & 0,9981 & 0,9995 & 0,9959 & \\
Rendah & 0,9971 & 0,9988 & 0,9952 & R $\geq 0,990$ \\
Persentase perbedaan & $0,12 \%$ & $0,07 \%$ & $0,07 \%$ & \\
\hline
\end{tabular}

Nilai keseragaman noise dapat dilihat pada Tabel 5. Terlithat bahwa kedua protokol pada tiga CT Scan menghasilkan nilai yang masih masuk dalam batas ambang BAPETEN. Hal ini berarti sistem CT Scan dapat menghasilkan citra yang memiliki tingkat noise yang seragam pada semua posisi. Diantara ketiga pesawat, persentase perbedaan keseragaman noise terbesar antara protokol dosis tinggi dan dosis rendah yang dihasilkan pada pesawat Siemens yaitu $86,15 \%$.

Tabel 5. Hasil Keseragaman noise dari 3 modalitas CT Scan

\begin{tabular}{ccccc}
\hline \multirow{2}{*}{ Protokol } & \multicolumn{3}{c}{ Modalitas CT Scan 16 Slice } & \multirow{2}{*}{$\begin{array}{c}\text { Ambang batas } \\
\text { BAPETEN }\end{array}$} \\
\cline { 2 - 3 } & Siemens & GE & Toshiba & \\
\hline Tinggi & 1,12 & 0,94 & 1,00 & \multirow{2}{*}{ SD $\leq \pm 2$ CT } \\
Rendah & 1,99 & 1,94 & 1,74 & \\
Selisih & $77,67 \%$ & $86,15 \%$ & $74 \%$ & \\
Perbedaan & & & &
\end{tabular}

Nilai CNR menyatakan kemampuan sistem pencitraan dalam menghasilkan citra yang dapat menunjukkan kontras antara objek dan background. Semakin tinggi nilai CNR, maka semakin baik kualitas citra. Berdasarkan Tabel 6, terlihat bahwa terdapat penurunan yang cukup signifikan antara CNR dengan protokol dosis tinggi dan dosis rendah pada ketiga CT Scan. Perbedaan terbesar didapat pada CT Scan GE, yaitu 93,45\%. Hal ini berarti perubahan protokol dari dosis tinggi (faktor eksposi tinggi) ke protokol dosis rendah (faktor eksposi 
rendah) memberikan pengaruh yang siginifikan terhadap nilai CNR. Perbedaan CNR ini dapat dilihat lebih jelas pada grafik profil yang dibuat menggunakan imageJ pada Gambar 5. Terlihat bahwa perbedaan antara kontras dan noise paling terlihat jelas pada protokol dosis tinggi. Semakin tinggi faktor eksposi, semakin baik $\mathrm{CNR}^{[22]}$.

Tabel 6. Pengukuran CNR dari 3 modalitas CT scan 16 Slice

\begin{tabular}{cccc}
\hline Protokol & \multicolumn{3}{c}{ Hasil Pengukuran CNR dari Merk CT Scan } \\
\hline & Toshiba & Siemens & GE \\
\hline Tinggi & 77,71 & 364,50 & 178,59 \\
Rendah & 26,92 & 37,16 & 8,66 \\
Persentase perbedaan & $65,52 \%$ & $89,80 \%$ & $93,45 \%$ \\
\hline
\end{tabular}

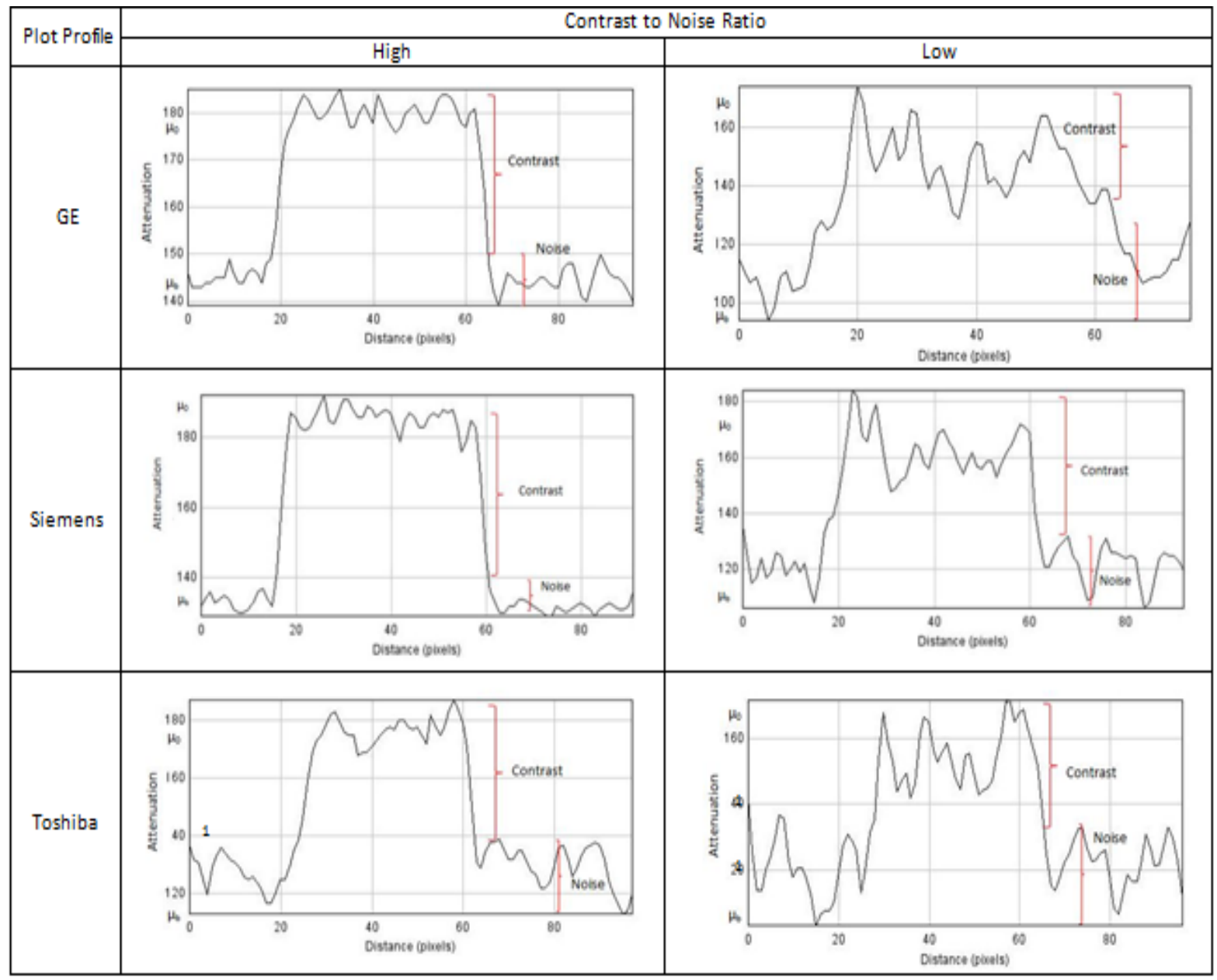

Gambar 5. Grafik profil untuk melihat contrast dan noise

Nilai resolusi spasial menggambarkan kemampuan sistem pencitraan untuk dapat mencitrakan objek yang kecil, berhubungan dengan ketelitian, sehingga semakin kecil nilainya maka resolusi spasial semakin baik. Berdasarkan Tabel 7 , terlihat terdapat perbedaan yang tidak signifikan pada nilai resolusi spasial yang diperoleh dari kedua protokol. Hal ini berarti perubahan faktor eksposi hanya merubah nilai resolusi spasial sebanyak $20-23 \%$. 
Tabel 7. Hasil resolusi spasial dari 3 modalitas CT scan

\begin{tabular}{cccc}
\hline Protokol & \multicolumn{3}{c}{ Resolusi Spasial } \\
\cline { 2 - 4 } & Toshiba & Siemens & GE \\
Tinggi & $1,0 \mathrm{~mm}$ & $0,8 \mathrm{~mm}$ & $0,8 \mathrm{~mm}$ \\
Rendah & $1,3 \mathrm{~mm}$ & $1,0 \mathrm{~mm}$ & $1,0 \mathrm{~mm}$ \\
Persentase perbedaan & $23,1 \%$ & $20 \%$ & $20 \%$ \\
\hline
\end{tabular}

Nilai CTDIvol hasil kedua protokol dapat dilihat pada Tabel 8. Terlihat bahwa terdapat perbedaan yang sangat signifikan pada nilai CTDIvol pada protokol dosis tinggi dan dosis rendah. Hal ini berarti perubahan faktor eksposi dari tinggi ke rendah dapat mengurangi keluaran radiasi hingga 85-91\%. Jika dibandingkan dengan nilai IDRL (Indonesian Diagnostic Refference Levels) tahun 2020 dari BAPETEN, yaitu 11 mGy untuk chest scan dewasa, maka semua nilai CTDIvol dengan protokol dosis tinggi berada di atasnya. Hal ini berarti perlu ada justifikasi dan optimasi dalam penggunaan protokol dosis tinggi.

Berdasarkan hasil penelitian, terlihat bahwa pengurangan nilai CTDIvol hingga 85-91\% hanya mempengaruhi nilai CNR, sementara nilai keseragaman CT Number, linearitas CT Number, keseragaman noise, dan resolusi spasial tidak mengalami perbedaan yang signifikan. Penggunaan protokol dosis yang terlalu rendah memang memungkinkan mengurangi kualitas citra dan dapat mengganggu diagnosis ${ }^{[14]}$. Besaran CNR yang mengalami penurunan paling signifikan pada penelitian ini menunjukkan tingkat kontras objek dalam background ber-noise, sehingga penurunan CNR memungkinkan menurukan visibilitas objek dengan kontras rendah. Sehingga penerapan protokol dosis rendah baru bisa diterapkan untuk mencitrakan objek tertentu yang dapat dikategorika sebagai objek kontras tinggi, seperti pada pemeriksaan CT Scan thorax. Thorax terdiri dari organ tulang rusuk, tulang dada, jantung dan paru-paru yang dikategorikan sebagai daerah kontras tinggi karena densitas antar organ sangat berbeda.

Tabel 8. Hasil CTDIvol dari 3 modalitas CT scan

\begin{tabular}{cccc}
\hline \multirow{2}{*}{ Protokol } & \multicolumn{3}{c}{ CTDIvol } \\
\cline { 2 - 4 } & Toshiba & Siemens & GE \\
\hline Tinggi & $15,60 \mathrm{mGy}$ & $20,32 \mathrm{mGy}$ & $26,85 \mathrm{mGy}$ \\
Rendah & $2,30 \mathrm{mGy}$ & $2,91 \mathrm{mGy}$ & $2,03 \mathrm{mGy}$ \\
Persentase perbedaan & $85,25 \%$ & $85,16 \%$ & $91,43 \%$ \\
\hline
\end{tabular}

\section{KESIMPULAN}

Penggunaan protokol dosis tinggi dan rendah menghasilkan perbedaan dalam kualitas citra CT Scan thorax. Namun, nilai akurasi, keseragaman, dan linearitas CT number serta keseragaman noise pada protokol dosis tinggi dan dosis rendah keduanya masih dalam batas ambang standar BAPETEN. Sementara itu, nilai CNR pada protokol dosis tinggi lebih baik dari pada protokol dosis rendah, dengan perbedaan signifikan, yaitu 65-95\%. Nilai resolusi spasial pada protokol dosis tinggi juga lebih baik daripada protokol dosis rendah, dengan perbedaan 20-23\%. Selain itu, nilai dosis keluaran CTDIvol juga menunjukkan perbedaan yang signifikan. Perubahan dari protokol dosis tinggi ke rendah, dapat mengurangi dosis 8591\%. Hasil ini menunjukkan bahwa penggunaan protokol dosis rendah dapat mengurangi 
dosis keluaran yang signifikan dengan tetap mempertahankan sebagian besar kualitas citra, kecuali nilai CNR.

\section{DAFTAR PUSTAKA}

1. Hausleiter J, Meyer T, Hermann F, Hadamitzky M, Krebs M, Gerber T C, McCollough C, Martinoff S, Kastrati A \& Schömig A. 2009. Estimated radiation dose associated with cardiac CT angiography. J. Am. Med. Assoc, 301 500-7.

2. Mulkens T., Salgado R., \& Bellinck P. 2011. Dose Optimization and Reduction in CT of the Brain and Head and Neck Region. In: Tack D, Kalra MK, Gevenois PA (eds.). Radiation Dose from Multidetector CT. Springer, Berlin, Heidelberg; 281-306.

3. Smith-Bindman R., Lipson J., \& Marcus R. 2009. Radiation dose associated with common computed tomography examinations and the associated lifetime attributable risk of cancer. Arch Intern Med, 169, 2078-2086.

4. European Commission. 2014. Radiation Protection No 180 Medical Radiation Exposure of the European Population, Publications Office of the European Union.

5. Dougeni, E., Faulkner, K. and Panayiotakis, G. 2012. A review of patient dose and optimisation methods in adult and paediatric CT scanning. Eur. J. Radiol, 81(4), e665e683.

6. Kalra, M.K., Maher, M.M., Toth, T.L., Kamath, R.S., Halpern, E.F., \& Saini, S. 2004. Comparison of $\mathrm{Z}$-axis automatic tube current modulation technique with fixed tube current CT scanning of abdomen and pelvis. Radiology, 232 (2), 347-353.

7. Kambadakone, A.R., Prakash, P., Hahn, P.F., \& Sahani, D.F. 2010. Low-dose CT examinations in Crohn's disease: impact on image quality, diagnostic performance, and radiation dose. Journal of the American College of Radiology, 195 (1), 78-88.

8. McLaughlin, P.D., Murphy, K.P., \& Hayes, S.A. 2014. Non-contrast CT at comparable dose to an abdominal radiograph in patients with acute renal colic; impact of iterative reconstruction on image quality and diagnostic performance. Insights into Imaging, 5 (2), 217-230.

9. Murphy, K.P., Crush, L., \& Twomey, M. 2015. Model-based iterative reconstruction in CT enterography. American Journal of Roentgenology, 205 (6), 1173-1181.

10. Sari, N.L.K., Suzana, M., Muslim, M., \& Muliyati, D. 2020. Analysis of the effect of care dose 4D software use on image quality and radiation dose on the CT scan abdomen. Spektra: Jurnal Fisika dan Aplikasinya, 5 (1).

11. Syamsidar, Abdullah, B., Dewang, S., \& Mulyadin. 2017. Analisis Akurasi dan Keseragaman CT Number dari Citra CT Scan menggunakan Phantom Gammex. Jurnal Pendidikan Fisika Universitas Hasanudin, 2(1), 2356-301X.

12. Davoudi, M., Khoramian, D., Firouzjah, R.A., \& Ataei, G. 2019. Strategy of computed tomography image optimisation in cervical vertebrae and neck soft tissue in emergency patients. Radiation protection dosimetry, 187 (1), 98-102.

13. Kalra M.K., Maher M.M., Toth T.L. 2004. Strategies for CT radiation dose optimization. Radiology, 230:619-28.

14. Kavanagh, R.G., O’Grady, J., Carey, B.W., McLaughlin, P.D., O’Neill, S.B., Maher, M.M., \& O'Connor, O.J. 2018. Low-Dose Computed Tomography for the Optimization of Radiation Dose Exposure in Patients with Crohn's Disease. Gastroenterology Research and Practice, Article ID 1768716.

15. BAPETEN. 2018. Peraturan kepala BAPETEN no. 2 tahun 2018 tentang Uji Keseuaian Pesawat Sinar-X Radiologi Diagnostik dan Konvensional. 
16. Bushberg, J.T. 2011. The Essential Physics Of Medical Imaging, Third Edition. Philadelphia, USA.

17. ICRU. 2012. ICRU report 87: Radiation Dose and Image-Quality Assessment in Computed Tomography. Journal of the ICRU Volume 12 No 1, Oxford University Press.

18. Afifi, M.B., Abdelrazek, A., Deiab, N.A., ElHafez, A.I.A., \& El-Farrash, A.H. 2020. The effects of CT x-ray tube voltage and current variations on the relative electron density (RED) and CT number conversion curves. Journal of Radiation Research and Applied Sciences, 13 (1), 1-11, DOI: 10.1080/16878507.2019.1693176.

19. Brent van der Heyden, Michel Öllers, André Ritter, Frank Verhaegen, Wouter van Elmpt. 2017. Clinical evaluation of a novel CT image reconstruction algorithm for direct dose calculations. Physics and Imaging in Radiation Oncology 2, 11-16

20. Seeram, E. 2016. Computed Tomography Physical Principles, Clinical Applications, and Quality Control, Fourt edition. Saunders.

21. Mackin, D., Ger, R., Dodge, C., Fave, X., Chi1, P.C., Zhang, L., Yang, J., Bache, S., Dodge, C., Jones, A.K., \& Court, L. 2018. Effect of tube current on computed tomography radiomic features. Scientific Reports, 8, 2354.

22. Alsleem, H.A., \& Almohiy, H.M. 2020. The Feasibility of Contrast-to-Noise Ratio on Measurements to Evaluate CT Image Quality in Terms of Low-Contrast Detailed Detectability. Med. Sci., 8, 26. 